\title{
Can information be too much? the moderating role of Covid-19 information on the effect of job stress on job performance
}

\author{
Adra Rida Mahila1 ${ }^{1}$ Rosaly Franksiska1 \\ ${ }^{1}$ Department of Management, Faculty of Economics and Business, Universitas Kristen Satya Wacana, Indonesia
}

\begin{tabular}{ll}
\hline Abstract & During the Covid-19 pandemic, many governments require companies to promote a work \\
from home policy. However, many occupations cannot be done at home, putting the \\
employees at increased health risk and increasing job stress. The purpose of this study is \\
to examine whether job stress negatively affects job performance. Furthermore, we also \\
examine the moderating effect of Covid-19 information on the relationship between job \\
stress and job performance. Our respondents are employees who work in manufacturing \\
firms in Salatiga and still have to work from the office during the pandemic. The data were \\
collected using an online questionnaire, and the total number of respondents is 105. Our \\
analysis using moderated regression analysis founds that job stress negatively influences \\
job performance. We also found that Covid-19 information moderates the relationship \\
between job stress and job performance.
\end{tabular}

\section{INTRODUCTION}

Job stress is currently a common problem among employees in this new era, and the research on it has been increasing significantly (Ganster \& Rosen, 2013). Job stress happens to everyone who has ever worked. According to Kotteeswari and Sharief (2014), the business process outsourcing (BPO) industry in India has always been characterized as ungodly hours, monotonous jobs, and low perceived value is believed to be the determinant of job stress. In some cases, stress might be caused by low salaries, excessive workloads, annoying colleagues, lack of support from supervisor, hazardous conditions, job insecurity, and the increasing pace of life (Kotteeswari \& Sharief, 2014; Yozgat et al., 2013).

During the Covid-19 pandemic, many governments demand that business owners change the conventional work from the office method to work from home. The governments argue that work from home is necessary to maintain physical distancing as a generally accepted way to reduce the risk of the spread of Covid-19. Most people also might want to stay in their house and keep their families safe. Metova (2021) conducted a survey and found that $57 \%$ of respondents who were newly working from home because of the pandemic prefer to work from home.

Unfortunately, many workers still have to go to the office during this Covid-19's outbreak, especially workers from the manufacturing industry. They are not allowed to work from home because manufacturing firms believe that they will gain higher productivity levels when the workforce is in the worksite (Philip, 2020). Baker (2020) stated that jobs that can be done at home are only the ones that require limited interaction with the public and did not need to rely on others. This circumstance puts the employees at increased health risk. As suggested by Kotteeswari \& Sharief (2014) and Yozgat et al. (2013), this hazardous situation may increase job stress.

On the other hand, the workers that experience job stress will not be able to satisfy job demands, and it can cause the quality of their work-life to decrease (Sheraz et al., 2014). Stress in the workplace also affects work productivity and quality (Blumberga \& Ziedina-Lagzdona, 2014) and significantly reduces an individuals performance (Bashir \& Ramay, 2010). In turn, job performance will affect not only employees but also the companies. 
However, to the extent of our knowledge, there are still limited empirical studies examining the job stress issue and its relation to job performance in the context of the Covid-19 pandemic. Therefore, our study attempts to fill this gap by examining the effect of job stress on job performance for employees who must work from office during the pandemic.

Another issue that is also essential to be explored is related to Covid-19 information. Since the pandemic has affected worldwide, the news has been found overwhelming. Its coverage has caused the general public to feel dazed and even plunged into anxiety and panic. The news spreads faster through mobile phones, worsening the anxiety and panic of the public (Dong \& Zheng, 2020). Therefore, our study also examines the moderating effect of Covid-19 information on job stress on job performance. We predict that the negative effect of job stress on job performance is higher for individuals who get too much Covid-19 information.

This research was held in Indonesia during Covid-19 pandemic. The chosen respondents are staffs that work in a factory. They are chosen to be the object here because they still have to work during Covid19 's outbreak. During this pandemic, the Indonesian government announced a Large Scale Social Restriction (PSBB), but Sutrisno (2020) stated that 200 large companies have already gotten permission from the Industry Ministry to operate during PSBB.

\section{LITERATURE REVIEW AND HYPOTHESES DEVELOPMENT}

\section{Job stress}

Job stress is a disease caused by workplace conditions that will negatively affect an individual's performance, body, and mind (Kotteeswari \& Sharief, 2014). There are two reasons why job stress is essential, one economic and one humanitarian. Direct and indirect organizational costs result from mismanaged job stress. In addition, physical and emotional sufferings in the workplace are the cause of mismanaged job stress (Quick et al., 2016).

Demands that appear in the work environment or by contextual or non-work demands can trigger job stress. It can have spill-over effects into the workplace, in part through role conflicts. The standard categories of job stressors are physical demands, task demands, role demands, and interpersonal demands. There are also extra-organizational stressors, and the example is marital discord and transitional factors such as preparing for retirement. Examining the entire life experience (during work and not) is essential to understand an individual's stress and strain (Quick et al., 2016).

Job stress are believed to cause cognitive, physical, psychological, and behavioral outcomes (Gershon et al., 2009; Romadhon et al., 2017). Stress will cause difficulties in focusing, make decisions, and recall information. Chronic stress has been linked to depression, anxiety, phobias, and panic attacks. One of the most common physical reactions to stress is the tensing of the muscles, leading to tension headaches, migraines, and other musculoskeletal conditions. Stress can also cause a problem in the digestive system. It will lead to the nutrition not being well spread to the body. This can cause nausea, pain, vomiting, heartburn, reflux, or diarrhea. Chronic stress can also lead to bad eating habits (Terrapin Adventures, 2017). Behavioral symptoms are persistent or repetitive behaviors that are unusual, disruptive, inappropriate, or cause problems. Aggression, criminal behavior, defiance, drug use, hostility, inattention, and secrecy are examples of behavioral symptoms (Healthgrades, 2018). Cognitive symptoms of stress include constant worrying, racing thoughts, forgetfulness and disorganization, inability to focus, poor judgment, pessimism, or seeing only the negative side (Web MD, 2019).

\section{Covid-19 information}

The Covid-19 outbreak started in December 2019. The virus came from Wuhan, China (Radulescu \& Cavanagh, 2020). Due to hundreds of millions of people traveling during the Spring Festival period, the number of Covid-19 patients increased dramatically. People were asked to either quarantine themself or do a social distancing. The virus had been underestimated until the National Health Commission classified it as a B type infectious disease officially and took actions to fight against this disease on 20 January, 2020. Ever since then, epidemic prevention was comprehensively upgraded and marked the real beginning of universal concern, 
indicating widespread impacts (S. Li et al., 2020). Radelescu and Cavanagh (2020) stated that less than three months, the virus has spread and affected 193 countries and territories, with more than 400,000 worldwide infections, and still has not stopped growing.

In many regions, public anxieties and worries have decreased (Chung-Ying, 2020). Pandemics can lead to heightened stress and anxiety levels, which is a typical response to any stressful situation. More than $80 \%$ of the people were preoccupied with the thoughts of Covid-19. General populations reported suffering from sleep difficulties, paranoia about acquiring Covid19 infection, and distress-related social media during this outbreak (Roy et al., 2020).

Covid-19 information is information posted on social media that causes the fear and stigma of the virus. Even though Covid19 information is out of organization control, it still can be used as a moderator. HR can use Covid-19 information as materials to educate the workers and help them to maximize their works.

Covid-19 information is measured by the response showed by the worker after receiving it. There are three responses: cognitive, behavioral, and emotional response. Cognitive response leads to the appraisals of the threat that the receiver has in response to an information. Behavioral response is a response that showed in order to maintain balance. An emotional response is a response that consist of grief and stress reaction (Schnoor, 2005).

\section{Job performance}

According to Muchhal (2014), job performance is the proficiency of someone who performs activities that contribute to the organization's technical core. This contribution can be both direct (in the case of production workers), or indirect (in managers or staff personnel). Another definition of job performance stated by $\mathrm{Biz}$ Educator (2016) is that job performance is the level that the employee successfully fulfills the factors included in the job description.

Job performance is used to measure whether a person is promoted, rewarded with a bonus, given additional responsibilities, or fired from the job. Low performance and not achieving the goals might be experienced as dissatisfying or even as a personal failure (Muchhal, 2014). That is why employers observe and track job performance. The employers do it by checking data on the number of sales that the employee achieves, the number of defects output done, or the number of customer complaints or compliments received about the person's work (BizEducator, 2016.

The workers who still have to go to work are at risk for exposure to get infected by the virus during this outbreak and are more likely to experience job displacement and disruption during all types of public health emergencies (Baker, 2020). The Covid-19's outbreak has created a particularly challenging environment for human resource management, with managers having to quickly venture into the "unknown unknowns" as they strive to help their workforce adapt to and cope with radical changes occurring in the work and social environment (Carnevale \& Hatak, 2020).

Job performance will be measured using three dimensions: traits, behavior, and results. Traits are characteristics of an individual that will lead to effective employee job performance (Ghani et al., 2016). Performance behavior is a measurable connection between result and behavior to achieve the result (Webers, 2012). Job performance will be seen through the workers' efficiency and achievements and their completion of work on a schedule (Hettiarachchi, 2014).

\section{Job stress and job performance}

Employees who still have to go to the office during this Covid-19's outbreak will feel at risk. As suggested by Kotteeswari \& Sharief (2014) and Yozgat et al. (2013), this hazardous situation may increase job stress. Kotteswari and Sharief (2014) stated that job stress is a disease caused by workplace conditions that will negatively affect individual's performance, body, and mind. Job stress is positively related to withdrawal behavior (Jamal, 1984). Muchhal (2014) said that job performance is the proficiency of someone who performs activities that contribute to the organization's technical core. According to Kotteeswari and Sharief (2014), job stress is negatively related to job performance, which means that the higher the job stress gets, the lower the job performance. Yozgat, Yurtkoru, and 
Bilginoglu (2013) also found a negative relationship between job stress and job performance.

The stress that the workers experienced during work also determines their performance level. When they are stressed, their mental energies will be drained. Instead of focusing on the task at hand, they start concentrating on the stressor and coping with it. The worker's performance suffers because their attention and energies are diverted to dealing with stress. Having role ambiguity and experiencing conflicting role demands are related to lower performance (BizEducator, 2016). Based on that, this research would like to propose the following hypothesis.

\section{H1: Job stress negatively influences job performance.}

\section{Perception on Covid-19 information}

Mental health problems are positively associated with Social Media Exposure (SME) during the Covid-19 outbreak (Id et al., 2020). Covid-19 Information is an information posted on social media that can control the fear and stigma of the virus (Chung-Ying, 2020). Qian et al., (2005) stated that it would give a cognitive, behavioral, and emotional response to the receiver.

Stigma and xenophobia are two aspects of the societal impact of pandemic infectious outbreaks. During Covid-19 pandemic, wrong information and false reports about the Covid-19 have spread all over social media and caused fears among netizens. That is the reason that explains the association between frequently SMEs and mental health (Huaxia, 2020). Panic and stress have also been linked to such outbreaks (Jiloha, 2020).

The Covid-19 pandemic had an impact on police mental health at a time when the public needs them. Covid-19 social distancing policies caused many changes in protocols, including the requirements to wear personal protection equipment (PPE), patrolling routines, and shift schedules, and work hours that drive workplace stress. Besides, law enforcement is likely to experience increased high stress encounters with individuals suffering from mental health problems aggravated by fear of contagion and economic uncertainty (Stogner et al., 2020).
Medical staff, volunteers, and the general public will more or less experience vicarious traumatization during the spread and control of the Covid-19 pandemic. Nurses who fight against Covid-19 were generally found working under pressure because they suffered from anxiety (Mo et al., 2020). The general public and non-front-line nurses had significantly higher vicarious traumatization scores than the front-line nurses. It happens because front-line nurses have more vital psychological endurance (Z. Li et al., 2020). Based on that, this research would like to propose the following hypothesis.

H2: Covid-19 information positively moderates the effect of job stress on job performance.

\section{METHODS}

\section{Data collection}

This research uses a quantitative method. A correlational research design is employed in this research. The population of this research is people that work in factories. The sampling technique is purposive sampling. The chosen sample criteria are staff that works in manufacturing firms in Salatiga and also working during the Covid-19 pandemic. The data collection was held starting from September-November 2020.

However, the amount of the samples that will be used as a respondent is still not known. So, according to Ryan (2013), to determine the amount of the samples it can be done by multiplying all the dimensions that exist in the operationalization variable with 10. Based on that, the total of the sample that will be used in this research are minimum of 100 people. The hypothesis testing will be conducted using moderated regression analysis.

\section{Measurement}

Job stress was measured involving four dimensions: Cognitive, Physical, Behavioral, and Psychological, modified from Gershon et al., (2009) and Romadhon et al., (2017). Perception of Covid-19 information was measured using three dimensions: Cognitive Response, Behavioral Response, and Emotional Response from Qian et al., (2005). While job performance's measurement was from Ramawickrama et 
al. (2018) with three dimensions: Traits; Behavior; and Results.

\section{Characteristic of respondents}

105 respondents were involved in this research. All of the respondents are working in manufacturing firms. They also still have to go work during Covid-19 pandemic.

The respondents 105 workers who have to work during pandemic consist of 77 percent female and 33 percent male. The most dominating age group is $26-40$ years old, which is 49 percent. The 77 percent of the respondents are married. Almost half of the respondents, which is 47 percent already worked for more than 9 years. The person that worked for under 1 year is only 7 percent (Table 1).

\section{RESULTS AND DISCUSSIONS}

\section{Pretest}

The first test that is done is the validity test. The data is classified as valid if the sig $<\alpha=$ 0,05 . Based on the validity test result, all of the variables have a significancy more than $\alpha$, which means that the data is valid.

The second test is the reliability test using the Cronbach Alpha value. A variable will be considered as reliable if Cronbach Alpha value $>0.60$. Based on the reliability test result, all of the variable Cronbach Alpha value is more than 0.70 , which means that all the instruments of each variable Job stress, Covid-19, and job performance are accepted to be a variable measurement.

Table 1.

Characteristic of respondents

\begin{tabular}{|c|c|c|c|}
\hline \multicolumn{2}{|c|}{ Characteristic of Respondents } & Frequency & Percentage \\
\hline \multirow[t]{3}{*}{ Gender } & Male & 24 & $23 \%$ \\
\hline & Female & 81 & $77 \%$ \\
\hline & Total & 105 & $100 \%$ \\
\hline \multirow[t]{4}{*}{ Age Group } & $18-25$ & 20 & $19 \%$ \\
\hline & $26-40$ & 51 & $49 \%$ \\
\hline & $>40$ & 34 & $32 \%$ \\
\hline & Total & 105 & $100 \%$ \\
\hline \multirow[t]{3}{*}{ Marital Status } & Single/In Relationship & 27 & $26 \%$ \\
\hline & Married & 78 & $74 \%$ \\
\hline & Total & 105 & $100 \%$ \\
\hline \multirow[t]{15}{*}{ Job Position } & Cultivation & 10 & $10 \%$ \\
\hline & Clinic/health & 9 & $9 \%$ \\
\hline & Supervisor & 4 & $4 \%$ \\
\hline & Purchasing & 6 & $6 \%$ \\
\hline & $R \& D$ & 4 & $4 \%$ \\
\hline & Public relations & 7 & $7 \%$ \\
\hline & Internal Control & 3 & $3 \%$ \\
\hline & Finance & 7 & $7 \%$ \\
\hline & HR & 12 & $11 \%$ \\
\hline & Warehouse & 5 & $5 \%$ \\
\hline & General Affair & 17 & $17 \%$ \\
\hline & Customer Service & 4 & $4 \%$ \\
\hline & Sales & 2 & $2 \%$ \\
\hline & Others & 15 & $14 \%$ \\
\hline & Total & 105 & $100 \%$ \\
\hline \multirow[t]{6}{*}{ Length of Work } & $<1$ year & 7 & $7 \%$ \\
\hline & 1-3 year & 19 & $18 \%$ \\
\hline & 4-6 year & 16 & $15 \%$ \\
\hline & 7-9 year & 14 & $13 \%$ \\
\hline & $>9$ year & 49 & $47 \%$ \\
\hline & Total & 105 & $100 \%$ \\
\hline
\end{tabular}




\section{Hypothesis testing}

Variable $X$ and $Z$ will be stated as affecting variable $Y$ if sig $<0.05$. In this paper, $\mathrm{H}_{1}$ stated that job stress negatively influences job performance. From table 5, it can be seen that job stress has sig $0.000(p<0.05)$. In table 5, it also showed that both variables have negative unstandardized beta value. It could be concluded that $\mathrm{H} 1$, which stated that job stress negatively influences job performance, is significant and accepted.

The $\mathrm{H} 2$ stated that Covid-19 information moderates the relationship between job stress and job performance. In the hypothesis test table, it can be seen that Covid-19 information has sig 0.007 ( $p<$ $0.05)$. The $R$ Square shows that the influence of job stress is increasing when Covid-19 information is involved. It could be concluded that $\mathrm{H} 2$ which stated that Covid19 information moderates the relationship between job stress and job performance, is also significant and accepted. It can be seen from the $R$ square, it turned out to be higher after being moderated with perception on Covid-19 information, the influence increase to $21.2 \%$.

The test that was already done above shows that job stress negatively affects job performance. If job stress increase by $1 \%$, job performance will decrease as much 1.486. One of the cognitive symptoms that happen to the worker when there is a lot of pressure in the office is that they tend to be unfocused while working. This phenomenon is called "choking". Choking means performing worse than daily skill level dictates or what usually performed in the past because of a stressful situation. It happened because the ability to work memory during a stressful moment is slowing down. Working memory is a cognitive power that helps people focus on things that can solve a problem or task and decide what is relevant or irrelevant (O'Callaghan, 2020).

When there is much pressure in the office, workers feel their muscles tensing up. Fear, anger, and frustration register in the body's muscles, leading to muscle tension symptoms. Besides the emotional turmoil, muscle tension symptoms can happen in a modern office. With the new technology that exists, get up and move around is no longer needed when anything could be done with a computer or gadget. In a modern office, tensing muscles happen because of the lack of movement (Goleman \& Goleman, 1986).

Job stress is not affecting worker's behavior. It has an effect, but the effect is low. It might happen because of the different cultures that exist. The indicator used to measure the effect of job stress on workers' behavior is whether they consume alcoholic water and smoke. It is the opposite of the culture that exists in this small city.

Perception of Covid-19 information has a negative effect on job performance. If perception on Covid-19 increases by $1 \%$, job performance will decrease as much 1.176. People believe that Covid-19 put their life and health in danger. The fear that they might get infected and harming their family member can affect the worker's mind.

Covid-19 information moderates the relationship between job stress and job performance. When it is only job stress affecting job performance, the influence is $11.4 \%$, but when perception on Covid-19 information is added, the influence increases to $21.2 \%$. The workers have to do Covid-19 protocol and wearing personal protective equipment while working. It might cause physical weight. They also angry when seeing a co-worker disobeying Covid-19 protocol (Giorgi et al., 2020).

Mental well-being of workers can be deeply affected by the conflict between procedures for worker's safety and the need to provide support, and longer working hours. Because of that, it might cause workers to develop some behavioral, physical, and psychological reactions. The behavioral reactions might affect workers' performance poorly. The physical reactions can cause a headache and gastric disturbance, and the psychological might lead to low motivation, depressive thoughts,

Table 5.

Hypothesis testing

\begin{tabular}{lccccc}
\hline \multicolumn{1}{c}{ Variable } & Variable $\mathbf{Y}$ & $\begin{array}{c}\text { Unstandarized } \\
\text { Beta }\end{array}$ & Sig & Summary & $\mathbf{R}^{\mathbf{2}}$ \\
\hline Job Stress & $\begin{array}{l}\text { Job } \\
\text { Performance }\end{array}$ & -1.486 & 0.000 & H1 is supported & 0.114 \\
\hline $\begin{array}{l}\text { Job stress }{ }^{*} \text { Covid- } \\
19 \text { Information }\end{array}$ & $\begin{array}{c}\text { Job } \\
\text { Performance }\end{array}$ & -1.176 & 0.007 & H2 is supported & 0.212 \\
\hline
\end{tabular}


and mood swings to the workers (World Health Organization, 2020).

\section{CONCLUSION}

In sum, this research shows the response of the worker when they have to go to work during this global pandemic. This research found that job stress has negative effect toward job performance. It also found that Covid-19 information moderates the relationship between job stress and job performance.

Workers should be more educated about the importance of obeying Covid-19 protocol. It can be seen from the data that workers get irritated when seeing other workers disobey Covid-19 protocol. This would bring emotional stress to them. HR department expected to find a way to make the worker's job more efficient after knowing what the workers face or feel while working during this global pandemic.

There are some limitations to this study. This research was done during the peak case of Covid-19 Indonesia. That is why the questionnaires were spread online through a google form. This causes the research has slow progress since it takes a long time to collect responses.

Future research suggests using the traditional collecting response method, which is paper-based, might have a fast result. This research is also collecting data through questionnaire only, which might cause bias for the respondent. Because of that, the author can not control the respondent's answers. It would be better for the following research also to add interview in the data collecting method.

The other limitation is that Salatiga did not have many cases found if it were compared with the other city. That impacting the results of perception on Covid-19 information average become moderates, it can be seen from the data. If this research is re-done in a city with high Covid-19 cases found, the result might be different. Future research should be conducted in a city with high cases of Covid-19.

\section{REFERENCES}

Baker, M. G. (2020). Who cannot work from home? Characterizing occupations facing increased risk during the Covid19 pandemic using 2018 BLS data. Covid 19, 3.
Bashir, U., \& Ramay, M. I. (2010). Impact Of Stress On Employees Job Performance A Study On Banking Sector Of Pakistan. International Journal of Marketing Studies, 2(1), 122-126. https://doi.org/10.5539/ijms.v2n1p122

Bhat, A. (n.d.). What Is a Correlational Study? Definition with Examples. QuestionPro.Com. https://www.questionpro.com/blog/corre lational-research/amp/

BizEducator. (2016). Importance of Job Performance What Are the Major Predictors of Job Performance? BizEducator. https://www.bizeducator.com/importanc e-of-job-performance/

Blumberga, S., \& Ziedina-Lagzdona, I. (2014). Job stress, coping strategies and professional deformation of Human resource managers. Rural Environment, Education, Personality (Reep): Proceedings of the 7Th International Scientific Conference, 7, 218-222.

Carnevale, J. B., \& Hatak, I. (2020). Employee adjustment and well-being in the era of Covid-19: Implications for human resource management. Journal of Business Research, 116, 183-187. https://doi.org/10.1016/j.jbusres.2020.0 5.037

Chung-Ying, L. (2020). Social Reaction toward the 2019 Novel Coronavirus (Covid-19). Department of Rehabilitation Sciences, Faculty of Health and Social Sciences, March, https://doi.org/10.4103/SHB.SHB

Dong, M., \& Zheng, J. (2020). Letter to the editor: Headline stress disorder caused by Netnews during the outbreak of Covid19. Health Expectations, 23(2), 259260. https://doi.org/10.1111/hex.13055

Ekienabor, E. E. (2016). Impact of Job Stress on Employees' Productivity and Commitment. International Journal for Research in Business, Management and Accounting I, 2(5), 124-133. https://pdfs.semanticscholar.org/f436/6c 05609c46242f050d1f36848265e918e2 8b.pdf

Endriana, S. L. (2020). Stress Akibat Kerja. Prodiaohi.Co.Id. https://prodiaohi.co.id/stress-akibatkerja

Ganster, D. C., \& Rosen, C. C. (2013). Work Stress and Employee Health: A Multidisciplinary Review. Journal of Management, 39(5), 1085-1122. 
https://doi.org/10.1177/0149206313475 815

Gershon, R. R. M., Barocas, B., Canton, A. N., Xianbin Li, \& Vlahov, D. (2009). Mental, physical, and behavioral outcomes associated with perceived work stress in police officers. Criminal Justice and Behavior, 36(3), 275-289. https://doi.org/10.1177/0093854808330 015

Ghani, N. M. A., Yunus, N. S. N. M., \& Bahry, N. S. (2016). Leader's Personality Traits and Employees Job Performance in Public Sector, Putrajaya. Procedia Economics and Finance, 37(16), 46-51. https://doi.org/10.1016/s22125671(16)30091-0

Ghozali, I. (2011). Aplikasi analisis multivariate dengan program IBM SPSS 19. Semarang: Badan Penerbit Universitas Diponegoro.

Giorgi, G., Lecca, L. I., Alessio, F., Finstad, G. L., Bondanini, G., Lulli, L. G., Arcangeli, G., \& Mucci, N. (2020). Covid-19-Related Mental Health Effects In The Workplace: A Narrative Review. International Journal of Environmental Research and Public Health, 17(21), 1-22. https://doi.org/10.3390/ijerph17217857

Goleman, D., \& Goleman, T. B. (1986). Relieving Stress: Mind Over Muscle. The New York Times Magazine. https://www.nytimes.com/1986/09/28/m agazine/relieving-stress-mind-overmuscle.html

Gorbiano, M. I., \& Arbi, I. A. (2020). Indonesia Ready to Produce Ventilators, Covid-19 Test Kits to Meet Skyrocketing Demand. The Jakarta Post. https://www.thejakartapost.com/news/2 020/04/16/indonesia-ready-to-produceventilators-Covid-19-test-kits-to-meetskyrocketing-demand.html

Healthgrades. (2018). Behavioral Symptoms. Healthgrades.Com.

https://www.healthgrades.com/rightcare/mental-health-andbehavior/behavioralsymptoms\#: :text=Behavioral symptoms are persistent or,are examples of behavioral symptoms.

Hettiarachchi, H. (2014). Impact of Job Satisfaction on Job Performance of IT Professionals: With Special Reference to Sri Lanka. April 2014.

Huaxia. (2020). Bat soup, Biolab, Crazy Numbers...Misinformation "Infodemic" on Novel Coronavirus Exposed. Www.Xinhuanet.Com. http://www.xinhuanet.com/english/2020 -02/04/c_138755586.htm

Id, J. G., Zheng, P., Jia, Y., Chen, H., Mao, Y., Chen, S., Wang, Y., Fu, H., \& Dai, J. (2020). Mental health problems and social media exposure during Covid-19 outbreak. February, 1-10. https://doi.org/10.1371/journal.pone.023 1924

Iswara, M. A. (2020). Indonesian Manufacturers Step as G20 Nations Coordinate Global Medical Supply. The Jakarta Post. https://www.thejakartapost.com/news/2 020/03/27/indonesian-manufacturersstep-up-as-g20-nations-coordinateglobal-medical-supply.html

Jamal, M. (1984). Job stress and job performance controversy: An empirical assessment. Organizational Behavior and Human Performance, 33(1), 1-21. https://doi.org/10.1016/00305073(84)90009-6

Jiloha, R. C. (2020). Covid-19 and Mental Health. Epidemiology International, 5(1), 9-11.

Kotteeswari, M., \& Sharief, T. S. (2014). Job Stress and Its Impact on Employees' Performance a Study With Reference To Employees Working in Bpos. International Journal of Business and Administration Research Review, 2(4), 18-25.

Li, S., Wang, Y., Xue, J., Zhao, N., \& Zhu, T. (2020). The Impact of Covid-19 Epidemic Declaration on Psychological Consequences: A Study on Active Weibo Users. International Journal of Environmental Research and Public Health, 17(6). https://www.mdpi.com/16604601/17/6/2032/htm

Li, Z., Ge, J., Yang, M., Feng, J., Qiao, M., Jiang, R., Bi, J., Zhan, G., Xu, X., Wang, L., Zhou, Q., Zhou, C., Pan, Y., Liu, S., Zhang, H., Yang, J., Zhu, B., Hu, Y., Hashimoto, K., ... Yang, C. (2020). Vicarious Traumatization in The General Public, Members, and Non-members of Medical Teams Aiding in Covid-19 Control. Brain, Behavior, and Immunity, March, 0-1. https://doi.org/10.1016/j.bbi.2020.03.00 7

Metova. (2021). Infographic: Insights On Working From Home During Covid-19. Metova.Com. https://metova.com/working-from-homeCovid-19/

Mo, Y., Deng, L., Zhang, L., Lang, Q., Liao, C., Wang, N., Qin, M., \& Huang, H. (2020). 
Work Stress Among Chinese Nurses to Support Wuhan for Fighting Against the Covid-19 Epidemic. Journal of Nursing Management. https://doi.org/10.1111/jonm.13014

Muchhal, D. S. (2014). HR Practices and Job Performance. IOSR Journal Of Humanities And Social Science, 19(4), 55-61.

O'Callaghan, T. (2011). Psychologist: Why We Screw Up When The Heat Is On. NewScientist.Com. https://www.newscientist.com/article/mg 21128200-200-psychologist-why-wescrew-up-when-the-heat-is-on/

Olivares, O. P., Juncal Ruiz, M., Fernández Abascal Puente, B., Gómez Revuelta, M., Pérez Herrera, M., Santayana Jenaro, G. P. de, Sánchez Blanco, L., Pérez Santos, A. B., Revillas Almajano, F. A. de las, Martín Gutiérrez, R., \& Landera Rodríguez, R. (2017). Cognitive symptoms in mayor depression: A study with vortioxetina. European Psychiatry, 41(S1), S538S538.

https://doi.org/10.1016/j.eurpsy.2017.01 .742

Philip, L. (2020). Covid-19 Impact: For Manufacturers, Work From Home Doesn't Work. The Economic Times. https://economictimes.indiatimes.com/n ews/company/corporate-trends/Covid19-impact-for-manufacturers-workfrom-home-doesntwork/articleshow/74569188.cms?from= $\mathrm{mdr}$

Qian, M., Ye, D., Zhong, J., Xu, K., Zhang, L., Huang, Z., Dong, W., Liu, X., Zhang, X., Zhang, Z., Wang, C., \& Nie, J. (2005). Behavioural, cognitive and emotional responses to SARS: Differences between college students in Beijing and Suzhou. Stress and Health, 21(2), 8798. https://doi.org/10.1002/smi.1043

Quick, J. C., Macik-Frey, M., \& Nelson, D. L. (2016). Job stress. The Curated Reference Collection in Neuroscience and Biobehavioral Psychology, December 2015, 467-474. https://doi.org/10.1016/B978-0-12809324-5.05616-9

Radulescu, A., \& Cavanagh, K. (2020). Management strategies in a SEIR model of Covid 19 community spread. 1-13. http://arxiv.org/abs/2003.11150

Ramawickrama, J., Opatha, H. H. D. N. P., \& Pushpakumari, M. D. (2018). Quality of Work Life and Job Performance: Empirical Evidence from Station
Masters Working at Sri Lanka Railways. Sri Lankan Journal of Human Resource Management, $8(1), \quad 1$. https://doi.org/10.4038/sljhrm.v8i1.5638

Romadhon, M. A., Fathoni, A., \& Haryono, A. T. (2017). Analisis Faktor-Faktor yang Mempengaruhi Stres Kerja Driver GoJek di Tegal. Journal Of Management, 6 , $1-7$.

Roy, D., Tripathy, S., Kar, S. K., Sharma, N., Verma, S. K., \& Kaushal, V. (2020). Study of knowledge, attitude, anxiety \& perceived mental healthcare need in Indian population during Covid-19 pandemic. Asian Journal of Psychiatry, 51, 102083. https://doi.org/10.1016/j.ajp.2020.10208 3

Ryan, P. T. (2013). Methods of Determining Sample Sizes. 17-55.

Sangaji, R. (2020). Companies Keep Doing Business in Palu Special Economic Zone Despite Outbreak. The Jakarta Post.

https://www.thejakartapost.com/news/2 020/04/17/companies-keep-doingbusiness-in-palu-special-economiczone-despite-outbreak.html

Schnoor, M. (2005). Emotional Response. MikeSchnoor.Com. https://mikeschnoor.com/2005/03/05/e motional-response/\#: :text=An Emotional Response is the, of this spectra of emotions.

Sheraz, A., Wajid, M., Sajid, M., Qureshi, W. H., \& Rizwan, M. (2014). Antecedents of Job Stress and its impact on employee's Job Satisfaction and Turnover Intentions. International Journal of Learning and Development, 4(2), 204226. https://doi.org/10.5296/ijld.v4i2.6098

Stogner, J., Miller, L., \& Mclean, K. (2020). Police Stress, Mental Health, and Resiliency during the Covid-19 Pandemic. 718730.

Sutrisno, B. (2020). Indonesia to Evaluate Partial Lockdown as Companies, Factories Continue Business as Usual. The Jakarta Post. https://www.thejakartapost.com/news/2 020/04/20/indonesia-to-evaluate-partiallockdown-as-companies-factoriescontinue-business-as-usual.html

Terrapin Adventures. (2017). The Physical and Physiological Effects of Stress on American Workers. TerrapinAdventures.Com. https://www.terrapinadventures.com/blo 
g/stress/\#: :text=On

the

Body\&text=This can cause nausea\%2C

pain, heart attack\%2C and even cancer.

Web MD. (2019). What are The Cognitive Symptoms of Stress? WebMD.Com. https://www.webmd.com/balance/stress -management/qa/what-are-thecognitive-symptoms-of-stress

Webers, N. (2012). Performance Behavior. https://www.managementboek.nl/code/i nkijkexemplaar/9789490670009/perfor mance-behavior-engels-neil-webers.pdf

World Health Organization. (2018). Occupational Safety and Health In Public Health Emergencies: In Ginebra, Suiza: World Health Organization. https://apps.who.int/iris/bitstream/handl e/10665/275385/9789241514347eng.pdf?ua $=1 \& u a=1$

Yozgat, U., Yurtkoru, S., \& Bilginoğlu, E. (2013). Job Stress and Job Performance Among Employees in Public Sector in Istanbul: Examining the Moderating Role of Emotional Intelligence. Procedia - Social and Behavioral Sciences, 75, 518-524. https://doi.org/10.1016/j.sbspro.2013.04 .056 